\title{
Mortality of Small Rodents Captured in Live-traps
}

\author{
W. I. MONTGOMERY 1
}

Montgomery W. I., 1980: Mortality of small rodents captured in livetraps. Acta theriol., 25, 22: 277-294 [With 11 Tables \& 2 Figs.]

This study reports the incidence and possible causes of trap deaths during a 30 month study of sympatric populations of the rodents Apodemus sylvaticus, A. flavicollis and Clethrionomys glareolus in western England. The overall incidence of trap deaths was highest among C. glareolus. Juveniles tended to be more vulnerable than adults. A. sylvaticus and C. glareolus with little or no previous experience of traps has a higher mortality rate; this was apparent in analyses within trapping periods of four days and also those concerning naive and experienced animals over a number of months. This result suggests that animals which perhaps constitute the migratory parts of rodent populations, are more susceptible to death in traps. Lighter animals of all species were also more likely to die in traps. There were positive correlations between the incidence of trap deaths among adults males, adult females and juveniles and interspecific comparisons suggest that seasonal changes in percentage trap mortality were similar in A. sylvaticus, A. flavicollis and C. glareolus. However factors associated with these changes seem to be different in all three species. Trap deaths of C. glareolus were most closely related to weather variables particularly low temperatures. In $A$. sylvaticus poor survival in the population as a whole was the major factor linked to death in traps. The proportion of $A$. flavicollis dying in traps declined as the trapping programme continued. This decline was not associated with any other factor, intrinsic or extrinsic, and it is speculated that intensive trapping effort on a small, patchily distributed population may have led to the selection of trap-resistant phenotypes which became increasingly more prevalent towards the end of the study.

[Dept. of Zoology, University of Manchester, England]

\section{INTRODUCTION}

There has been much discussion of the causes and incidence of mortality among rodents captured in live traps. Perrin (1975), for example, attributed the main causes of trap mortality in Microtus agrestis and Clethrionomys glareolus to extreme high or low temperature and excessive rainfall. This may be explained by Corke's experimental demonstration of a positive relationship between damp bedding and

1 Present address: Dept. of Zoology, Queen's University of Belfast, Belfast BT7 $1 \mathrm{NN}$, Northern Ireland. 
death in Longworth traps (C orke, 1967). Further, covering traps with waterproof insulation, or inserting additional protection inside the nest box, reduces trap mortality ( $\mathrm{Sh}$ aw \& Milner, 1967; Miller \& Getz, Iverson \& Turner, 1969). Intrinsic factors may also influence the survival of rodents in traps. Chitty (1959) has shown that confinement in traps can cause physiological stress in small mammals and Platt (1968) suggested that the incidence of trap deaths may reflect the degree of stress on animals at different population densities. Andrzejewski \& Wrockawek (1961) suggested that mortality is higher in the migratory part of rodent populations. The present paper reports the incidence of trap deaths during a $2^{1 / 2}$ year study of sympatric populations of the rodents Apodemus sylvaticus, A. flavicollis and C. glareolus. Trap mortality is analysed with respect to a number of methodological, biological and climatic variables in an attempt to assess the relative importance of extrinsic and intrinsic factors.

\section{STUDY AREA AND METHODS}

The study area, the mixed deciduous woodland and coniferous plantations of Woodchester Park, a valley in the limestone escarpment of the Cotswold Hills, Gloucestershire, England, was described in some detail in Y alden (1971) and M o ntgomery (1977, 1980a). Trapping, using Longworth live traps (Chitty \& Kempson, 1949) was carried out at approximately one month intervals from January 1974 to July 1976. Data reported here were derived chiefly from a 1 ha grid trapped for five consecutive nights every second month, and from three 0.5 ha grids trapped for four consecutive nights each month. Details of the trapping regimes were given in M o n t g o mer y $(1977,1980 \mathrm{a})$. Each Longworth trap contained dry hay and $2-3$ grams of wheat grain in the nest box. Bedding was changed when damp and food replenished on the release of captives. Otherwise bedding and food were replaced when the traps were cleaned each month. There was a single daily trap round each morning. All captured rodents were individually marked by a combination of toe clipping and ear punching (Fullagar \& Jewell, 1965), weighed, sexed and adults distinguished from juveniles on pelage characteristics ( $\mathrm{Fullag}$ a r, 1967).

\section{RESULTS}

\section{Intra- and Interspecific Variation in the Incidence of Trap Deaths}

The numbers of adult male, adult female and juvenile A. sylvaticus, $A$. flavicollis and $C$. glareolus handled and the number of trap deaths in each of these classes are presented in Table 1. In all three species, the proportions of trap deaths among males and females were similar. Juvenile trap mortality was significantly greater than that of adults cnly in C. glareolus $\left(\chi_{1}^{2}=12.78 ; P<0.005\right)$. A. sylvaticus and A. flavicollis did not differ with respect to the incidence of trap mortality but each 
Apodemus species, as a whole, was less susceptible than C. glareolus $\chi_{1}^{2}=46.58 ; P<0.005$ for $A$. sylvaticus; $\chi_{1}^{2}=47.91 ; P<0.005$ for $A$. flavicollis). Adult male and female and juvenile $C$. glareolus also suffered more from trap deaths than the corresponding classes in A. sylvaticus and A. flavicollis (Table 1). This result may have been due to the lack of an evening trap round throughout the trapping programme, causing individuals of the diurnal $C$. glareolus to suffer longer periods of confinement than the nocturnal Apodemus species.

Table 1

Numbers of adult male, adult female and juvenile A. sylvaticus, $A$. flavicollis and $C$. glareolus caught alive or dead throughout the study.

\begin{tabular}{lcrrr}
\hline & No. handled & No. live & No. dead & \% deaths \\
\hline & \multicolumn{4}{c}{ A. sylvaticus } \\
Males & 1266 & 1206 & 60 & 4.74 \\
Females & 950 & 911 & 39 & 4.11 \\
Juveniles & 248 & 235 & 13 & 5.24 \\
Total & 2464 & 2352 & 112 & 4.55 \\
& A. flavicollis & & \\
Males & 576 & 552 & 24 & 4.17 \\
Females & 467 & 451 & 16 & 3.43 \\
Juveniles & 303 & 295 & 8 & 2.64 \\
Total & 1346 & 1298 & 48 & 3.57 \\
& C. glareolus & & \\
Males & 329 & 298 & 31 & 9.42 \\
Females & 301 & 269 & 32 & 10.63 \\
Juveniles & 108 & 81 & 27 & 25.00 \\
Total & 738 & 648 & 90 & 12.20 \\
\hline
\end{tabular}

Table 2

Correlation coefficients $(r)$ and probability levels from intra- and interspecific comparisons of seasonal variation in the incidence of trap deaths.

\begin{tabular}{|c|c|c|c|}
\hline & $r$ & df & $P$ \\
\hline \multicolumn{4}{|l|}{ A. sylvaticus } \\
\hline male-female & 0.83 & 27 & $<0.001$ \\
\hline male-juvenile & 0.30 & 18 & $>0.1$ \\
\hline female-juvenile & 0.12 & 18 & $>0.1$ \\
\hline \multicolumn{4}{|l|}{ A. flavicollis } \\
\hline male-female & 0.83 & 27 & $<0.001$ \\
\hline male-juvenile & 0.31 & 14 & $\geq 0.1$ \\
\hline female-juvenile & 0.61 & 14 & $<0.02$ \\
\hline \multicolumn{4}{|l|}{ C. glareolus } \\
\hline $\begin{array}{l}\text { male-female } \\
\text { male-iuvenile }\end{array}$ & $\begin{array}{l}0.49 \\
0.55\end{array}$ & $\begin{array}{l}25 \\
12\end{array}$ & $\begin{array}{l}<0.02 \\
<0.05\end{array}$ \\
\hline $\begin{array}{l}\text { male-juvenile } \\
\text { female-juvenile }\end{array}$ & $\begin{array}{l}0.55 \\
0.07\end{array}$ & $\begin{array}{l}12 \\
12\end{array}$ & $\begin{array}{l}<0.05 \\
>0.1\end{array}$ \\
\hline female-juvenile & & $\begin{array}{l}12 \\
27\end{array}$ & $\geq 0.1$ \\
\hline A. sylvaticus-A, flavicollis & $\begin{array}{l}0.59 \\
0.59\end{array}$ & $\begin{array}{l}27 \\
27\end{array}$ & $<0.01$ \\
\hline A. sylvaticus-A. flavicollis & 0.59 & $\begin{array}{r}27 \\
7\end{array}$ & $\leq 0.01$ \\
\hline A. flavicollis-C. glareolus & 0.45 & 7 & $<0.02$ \\
\hline
\end{tabular}


Seasonal variation in the incidence of trap deaths of each species as a whole is illustrated in Figure 1 and correlation coefficients from intra- and interspecific comparisons are presented in Table 2. There were significant positive relationships between the incidences of trap death in adult males and females in all three species. There was also general accord between adults and juveniles though this was significant only in the comparison of female with juvenile A. flavicollis and male with juvenile $C$. glareolus. Interspecific comparisons indicate that seasonal changes in susceptibility to trap death were the same in all three species though $A$. sylvaticus and A. flavicollis were more like each other than C. glareolus (Table 2; Figure 1).
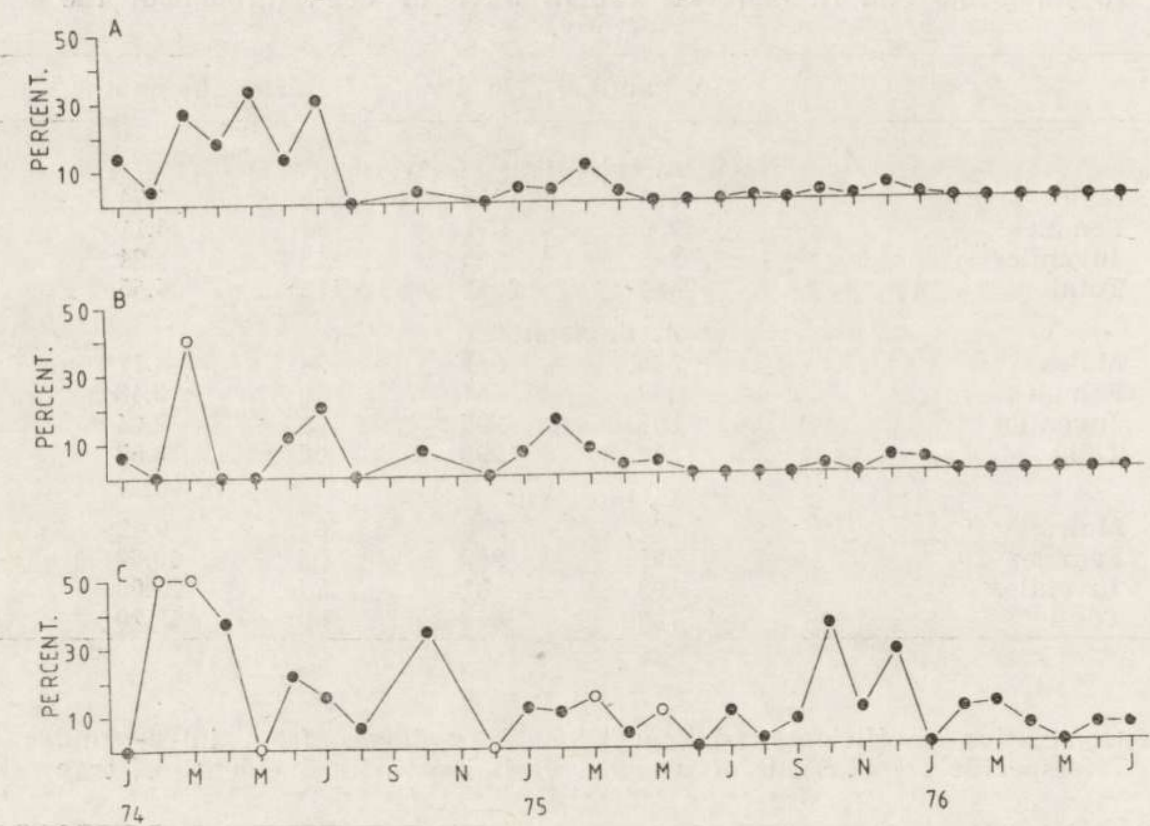

Fig. 1. Seasonal variation in the percentage of animals handled which died in traps. Open circles indicate samples of less than 10 animals. $\mathrm{A}=A$. sylvaticus $\mathrm{B}=A$. flavicollis, $\mathrm{C}=\mathrm{C}$. glareolus.

\section{Trap Deaths and Trapping Regimes}

Perrin (1975) reported an increase in the number of trap deaths of C. glareolus towards the end of a four day trapping period. This was indicated for this species in the present study but the observed distribution of trap deaths did not differ significantly from the expected number calculated from the proportion of the total number of captures of live voles which occurs on any day (Table 3). Animals which died in traps were omitted from the calculation of the expected numbers 
ssince these would have biased the outcome of the analyses towards ia limited number of previous captures. In A. sylvaticus and A. flavi(collis, the incidence of trap death throughout the trapping period also (did not differ significantly from the distribution of live captures (Table

\section{Table 3}

Total numbers of captures, alive and dead, on three grids trapped for four nights each month between January 1975 and July 1976. $\chi^{2}$ values trapped for four cobserved distribution of trap deaths and the expected distribution based on the distribution of live animals.

\begin{tabular}{|c|c|c|c|c|}
\hline $\begin{array}{l}\text { Day of } \\
\text { capture }\end{array}$ & $\begin{array}{l}\text { No. live } \\
\text { capt. }\end{array}$ & $\begin{array}{l}\text { No. dead } \\
\text { capt. }\end{array}$ & $\begin{array}{l}\text { Exp. no. } \\
\text { dead }\end{array}$ & \\
\hline 1 & 649 & 12 & 14.02 & \multirow{4}{*}{$\begin{array}{l}\text { A. sylvaticus } \\
\chi^{2}=3.52 \text {, df } 3 ; P>0.1\end{array}$} \\
\hline 2 & 657 & 20 & 14.20 & \\
\hline 3 & 667 & 14 & 14.41 & \\
\hline 4 & 619 & 10 & 13.37 & \\
\hline 1 & 336 & 7 & 6.59 & \multirow{4}{*}{$\begin{array}{l}\text { A. flavicollis } \\
\chi^{2}=7.19 \text {, df } 3 ; P<0.1\end{array}$} \\
\hline 2 & 379 & 13 & 7.44 & \\
\hline 3 & 384 & 3 & 7.53 & \\
\hline 4 & 379 & 6 & . 7.44 & \\
\hline 1 & 83 & 6 & 7.38 & \multirow{4}{*}{$\begin{array}{l}\text { C. glareolus } \\
\chi^{2}=3.59 \text {, df } 3 ; P>0.1\end{array}$} \\
\hline 2 & 118 & 6 & 10.49 & \\
\hline 3 & 143 & 15 & 12.71 & \\
\hline 4 & 151 & 17 & 13.42 & \\
\hline
\end{tabular}

Table 4

Number of previous captures of animals caught alive and those caught dead on the day of their last capture during a four day period. Data from three grids trapped at monthly intervals from January 1975 to July $1976 . \chi^{2}$ values compare the observed number of previous captures of animals which die in traps with the expected number of previous captures calculated from the frequency distribution of previous captures of animals which are alive on their last day of

\begin{tabular}{|c|c|c|c|c|}
\hline $\begin{array}{l}\text { Number } \\
\text { of } \\
\text { previous } \\
\text { captures }\end{array}$ & $\begin{array}{c}\text { Animals } \\
\text { alive on } \\
\text { day of last } \\
\text { capture }\end{array}$ & $\begin{array}{c}\text { Animals } \\
\text { dead on } \\
\text { day of last } \\
\text { capture }\end{array}$ & $\begin{array}{l}\text { Expected } \\
\text { no. dead } \\
\text { on das of } \\
\text { last capture }\end{array}$ & \\
\hline $\begin{array}{l}0 \\
1 \\
2 \\
3\end{array}$ & $\begin{array}{l}390 \\
280 \\
294 \\
255\end{array}$ & $\begin{array}{r}33 \\
15 \\
8 \\
3\end{array}$ & $\begin{array}{l}19.53 \\
13.62 \\
13.94 \\
11.91\end{array}$ & $\begin{array}{l}\text { A. sylvaticus } \\
\chi^{2}=19.53 \text {, df } 3 \\
P<0.001\end{array}$ \\
\hline $\begin{array}{l}0 \\
1 \\
2 \\
3\end{array}$ & $\begin{array}{l}281 \\
191 \\
156 \\
121\end{array}$ & $\begin{array}{r}13 \\
10 \\
4 \\
2\end{array}$ & $\begin{array}{r}10.96 \\
7.49 \\
5.96 \\
4.58\end{array}$ & $\begin{array}{l}\text { A. flavicollis } \\
\chi^{2}=3.45 \text {, df } 3, P>0.1\end{array}$ \\
\hline $\begin{array}{l}0 \\
1 \\
2 \\
3\end{array}$ & $\begin{array}{r}216 \\
88 \\
54 \\
18\end{array}$ & $\begin{array}{r}39 \\
3 \\
4 \\
0\end{array}$ & $\begin{array}{r}22.80 \\
9.92 \\
6.32 \\
1.96\end{array}$ & $\begin{array}{l}\text { C. glareolus } \\
\chi^{2}=13.65 \text {, df } 3, P<0.01\end{array}$ \\
\hline
\end{tabular}

3). In accord with Ferns (1978), those animals with little or no previous experience of traps during a trapping period had a higher mortality rate; this is clearly shown in Table 4 where the death rates 
on the last day of trapping of individuals caught previously $3,2,1$ or 0 times are compared. This disparity was highly significant in A. sylvaticus and $C$. glareolus. Although $A$. flavicollis which died in traps tended to be naive animals, this trend was not as marked as in A. sylvaticus and C. glareolus, nor was it statistically significant.

During a long programme of trapping small mammals, it is inevitable that the researcher gains sexperience" which may alter the proportion of captured animals which die in traps. The percentage trap mortality declined towards the end of the study and clearly the incidence of trap deaths in 1975 and 1976 was lower than in 1974 (Fig. 1). This trend was examined in relation to an arbitrary "index of experience " where the first month was given the value of 1 , the second 2, the third, 3 and so on. There was a significant negative association between the monthly "index of experience " on the percentage trap deaths in all three species $(r=-0.64$, df $27 ; P<0.001$ for $A$. sylvaticus, $r=-0.44$, df $27 ; P<0.02$ for $A$. flavicollis and $r=-0.41$, df $27 ; P<0.02$ for $C$. glareolus). At this stage of the analysis it is uncertain whether this result reflects a causal relationship between sexperience" and trap deaths, gradual changes in other environmental and biological parameters towards the end of the study or, indeed, qualitative changes in the populations under study.

\section{Trap Deaths and Population Characteristics}

The percentage incidence of trap deaths among A. sylvaticus, A. flavicollis and C. glareolus was compared with three characteristics of these populations (Table 5). Population size was measured as the number 'of individuals per 100 trap nights of the whole trapping programme in any single month. Minimal survival, $P_{\min }$, ( Chitty \& $\mathrm{Phipps}$, 1966), was derived from the capture-mark-recapture data of the large grid trapped in most months of 1974 and the three smaller grids trapped each month between January, 1975 and July 1976. A measure of turnover of individuals, the percentage of the total number of animals which appear for the first time in any month, was also based on the aforementioned capture-mark-recapture data. There was relatively little association between any of these parameters and trap mortality. That between population size and trap deaths was particularly weak (Table 6). However in both Apodemus species there were negative associations between survival and trap deaths; this was stronger and also significant at the $5 \%$ level in $A$. sylvaticus. This suggests that when survival is good, there are relatively few trap deaths whereas, in periods when survival is generally poor, the incidence of trap deaths is increased, 


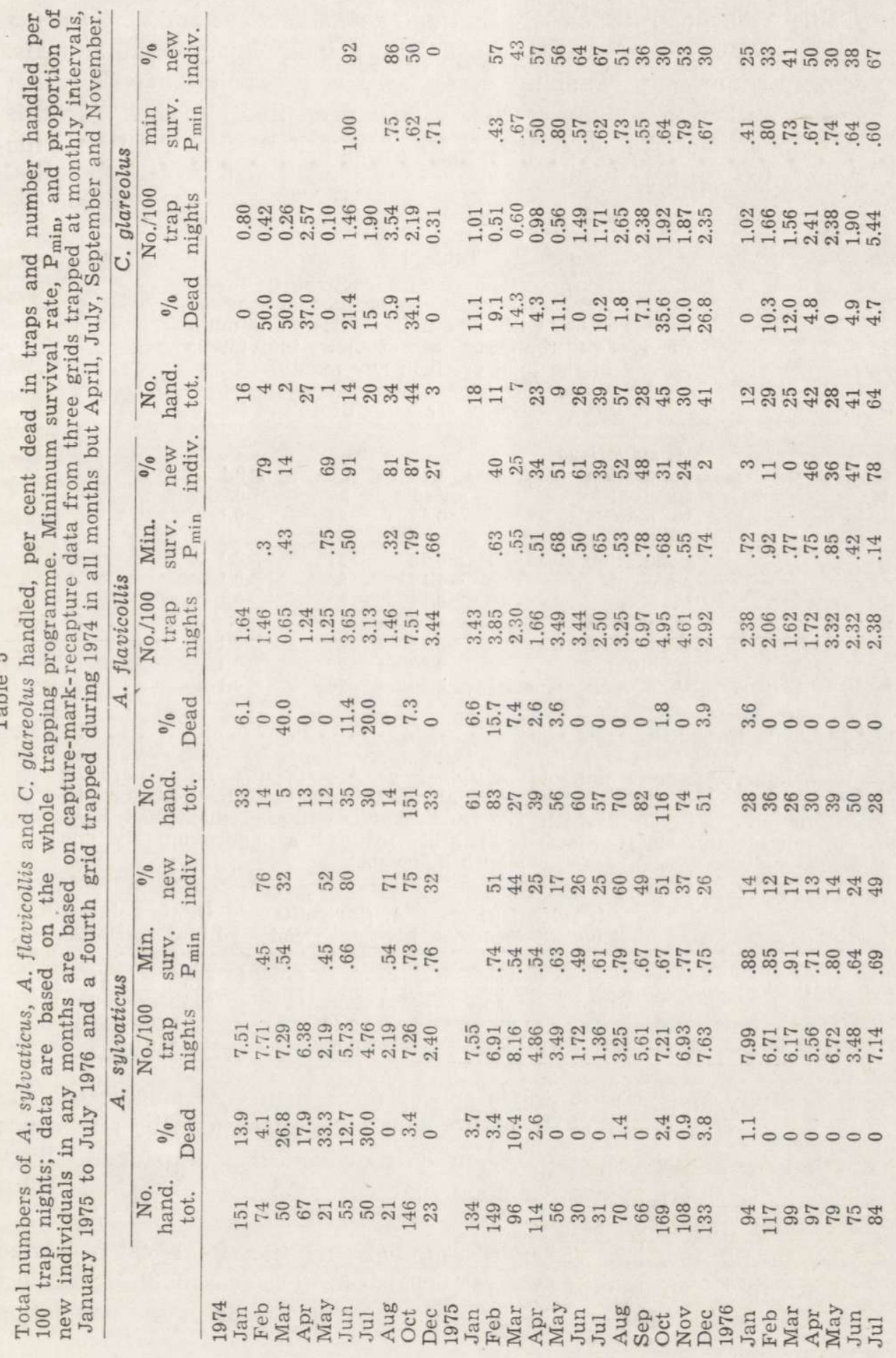


Table 4 demonstrates clearly that naive A. sylvaticus and C. glareolus were more vulnerable to death in traps than experienced animals, during a four day trapping session. A comparable analysis using monthly rather than daily capture data is presented in Table 7 . In this table "new" animals were those which appeared for the first time during any month and »old " animals were those which had been captur$\epsilon \mathrm{d}$ during at least one previous month. Data were lumped for the

Table 6

Correlation coefficients and probability levels from the comparisons of monthly percentage trap deaths with population size, minimum survival and the percentage of "new « individuals in the total catch in any month.

\begin{tabular}{lrrc}
\hline & $r$ & df & $P$ \\
\hline $\begin{array}{lrrl}\text { A. sylvaticus } \\
\text { population size }\end{array}$ & 0.03 & 27 & $\geq 0.1$ \\
survival & -0.48 & 23 & $<0.05$ \\
$\%$ new & 0.25 & 23 & $>0.1$ \\
$\begin{array}{l}\text { A. flavicollis } \\
\text { population size }\end{array}$ & -0.02 & 27 & $>0.1$ \\
survival & -0.15 & 23 & $>0.1$ \\
$\%$ new & -0.14 & 23 & $>0.1$ \\
C. glareolus & & & $>0.1$ \\
population size & -0.12 & 27 & $>0.1$ \\
survival & 0.20 & 20 & $<0.1$ \\
\% new & 0.36 & 20 & \\
\hline
\end{tabular}

Table 7

Numbers of "new « and »old" A. sylvaticus, A. flavicollis and C. glareolus caught alive and dead. "New" animals were those caught for the first time in any month and "old " animals those which had been caught previously. (Data from grids trapped at approximately one month intervals.)

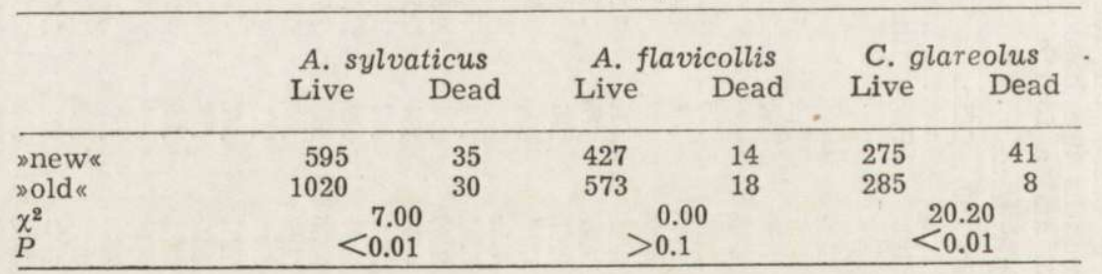

entire study and many animals appear more than once since a proportion of "new « animal were captured in subsequent months and hence entered the »old" category. Again it is evident that trap deaths were significantly more frequent among »new « $A$. sylvaticus and C. glareolus than among »old« ones.

As the proportion of "new « animals in the total catch varied considerably from month to month (Table 5), it is reasonable to suspect that this could influence the incidence of trap deaths in the population 
as a whole. This is indeed the case in A. sylvaticus and C. glareolus where there were weak positive relationships between the proportions cf "new " animals in monthly catches and trap deaths (Table 6). While more data are needed to confirm these relationships, the present study suggests that when the number of "new « animals, which are perhaps transients, is high, then there may be an increase in the incidence of trap mortality.

Breeding in A. sylvaticus, A. flavicollis and C. glareolus at Woodchester Park was seasonal in all three years to the study. Reproduction in small rodents is energetically expensive and one might speculate

Table 8

Weight class distribution of animals handled alive and those found dead in traps during January-April 1974, November-April 1974, ' 75 and November-April 1975, '76. $\chi^{2}$ values compare the observed distribution of the weight of trap deaths and the expected frequency based on the weight distribution of live animals.

\begin{tabular}{crrrl}
\hline $\begin{array}{c}\text { Wt } \\
\text { class }\end{array}$ & $\begin{array}{c}\text { No. live } \\
\text { animals }\end{array}$ & $\begin{array}{c}\text { No. dead } \\
\text { animals }\end{array}$ & $\begin{array}{c}\text { Exp. no. } \\
\text { dead }\end{array}$ & \\
\hline 24 g & 74 & 0 & 1.31 & \\
$20-$ & 382 & 3 & 6.79 & A. sylvaticus $~$ \\
$16-$ & 615 & 1 & 10.87 & $\chi^{2}=105.74$, df $4 ; P<0.001$ \\
$12-$ & 252 & 15 & 4.71 & \\
$8-$ & 13 & 5 & 0.32 & \\
$>44$ g & 9 & 0 & 0.27 & \\
$40-$ & 24 & 1 & 0.74 & \\
$36-$ & 75 & 1 & 2.25 & \\
$32-$ & 102 & 1 & 3.05 & Alavicollis \\
$28-$ & 134 & 5 & 4.12 & \\
$24-$ & 106 & 2 & 3.20 & $\chi^{2}=36.98$, df $7 ; P<0.001$ \\
$20-$ & 39 & 3 & 1.25 & \\
$16-$ & 2 & 2 & 0.12 & \\
$>24$ g & 2 & 0 & 0.24 & C. glareolus \\
$20-$ & 18 & 1 & 2.25 & \\
$16-$ & 77 & 8 & 10.07 & $\chi^{2}=15.48$, df $4 ; P<0.01$ \\
$12-$ & 84 & 11 & 11.26 & \\
$8-$ & 5 & 5 & 1.18 & \\
\hline
\end{tabular}

that during the breeding season (here the breeding season is defined as the period during which more than $50 \%$ of females of any species are in reproductive condition (see Montgomery, 1977, 1980a) mature animals may be under physiological stress which could lead to increased trap mortality. This did not occur. In A. sylvaticus and A. flavicollis the proportion of trap deaths among adult individuals (sexes combined) did not increase significantly during the breeding season $\left(\chi_{1}^{2}=0.29, P>0.10\right.$ for $A$. sylvaticus; $\chi_{1}^{2}=2.82 ; P<0.10$ for $A$. flavicollis). Among adult $C$. glareolus, however, the proportion of trap deaths was significantly greater in the non-breeding season $\left(\chi_{1}^{2}=8.52\right.$, 
$P<0.01)$. This disparity was made up largely of seasonal differences in the female voles $\left(\chi^{2}=6.67 ; P<0.01\right)$, which were more liable to trap death between October and March. It seems likely that this association is not causal but rather that the high winter trap mortality is due to some other factor or factors. There was no discrepancy in the breeding condition of rodents which died in traps and those in the populations as a whole; those adults which died during the breeding season were usually in breeding condition and those which died during the non-breeding period were usually reproductively immature.

Sadleir (1965) and others have demonstrated the importance of adult male aggression towards juvenile conspecifics which survive relatively less well, particularly during the first part of the breeding season. This is well documented in A. sylvaticus (F low e r d e w, 1974; G a rnell, 1978) and potentially could affect the incidence of trap deaths among juveniles. If this was so, the proportion of juveniles dying in traps should decline during the second half of the breeding season. However there was no such change in death rate among juveniles during the first (before August) and second (August and after) halves of the breeding season in $A$. sylvaticus $\left(\chi_{1}^{2}=1.13, P>0.1\right), A$. flavicollis $\left(\chi_{1}^{2}=1.71, P>0.1\right)$ or $C$. glareolus $\left(\chi_{1}^{2}=2.43, P>0.1\right)$.

Table 9

Mean weight of individuals which died on traps and mean live weights of the same individuals recorded earlier in the trapping programme.

A. sylvaticus

$A$.
A. flavicollis

C. glareolus
All species

\begin{tabular}{|c|c|c|c|c|}
\hline $\begin{array}{l}\mathrm{n} \\
\text { Mean weight, alive } \bar{X}_{1} \\
\text { Mean weight, dead } \bar{X}_{2} \\
\% \text { n losing weight } \\
\bar{X}_{1} \text { as } \bar{X}_{2}, t \\
\text { Probability }\end{array}$ & $\begin{array}{l}30 \\
18.53 \\
17.77 \\
46.67 \\
\quad 0.82 \\
>0.1\end{array}$ & $\begin{array}{l}20 \\
30.75 \\
29.60 \\
60.00 \\
0.49 \\
>0.1\end{array}$ & $\begin{array}{l}10 \\
19.45 \\
16.95 \\
80.00 \\
1.76 \\
<0.1\end{array}$ & $\begin{array}{l}60 \\
22.76 \\
21,58 \\
56.67 \\
\quad 0.85 \\
>0.1\end{array}$ \\
\hline
\end{tabular}

Perrin (1975) found that C. glareolus which died in traps weighed less than those captured alive. Data presented here support this conclusion; trap deaths in C. glareolus and both Apodemus species tended to involve animals from lower weight classes (Table 8). Only data from winter months was used in this analysis since there is wide seasonal variation in weight class distribution of all three species (Montgomery, 1977, 1980a), and, in view of the variation in the incidence of trap deaths, this might have confounded results. Since this analysis depends on weights of dead animals, it could be argued that a loss of weight precedes or follows death and that the possibility that individuals of all weight classes were equally liable to trap death 
cannot be discounted. However comparison of dead weights with live weights of the same individuals, which were recorded within one month of dedath, indicates that although there was a small weight loss in each species, this loss was not statistically significant (Table 9). This suggests that weight loss before or after death was not an important factor and confirms Perrin's (1975) assertion that lighter weight classes are more vulnerable to death in traps.

\section{Trap Deaths and Weather}

The monthly incidence of trap deaths was examined in relation to a number of weather variables; weather data were those of the meteorological station at Cheltenham, Gloucestershire, some $20 \mathrm{~km}$ north of the study site. The variables examined were mean maximum, mean minimum and mean daily air temperature, number of days with grass

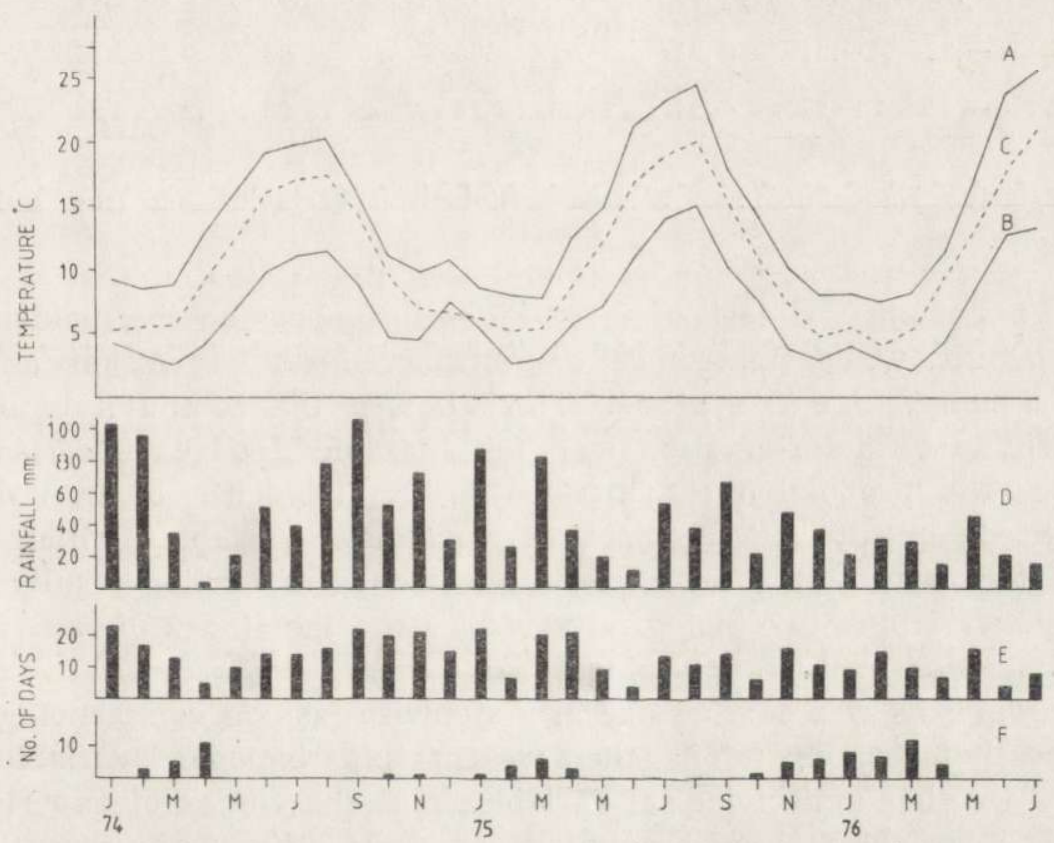

Fig. 2. Seasonal variation in selected climatic variables.

$\mathrm{A}=$ mean maximum temperature, ${ }^{\circ} \mathrm{C} ; \mathrm{B}=$ mean minimum temperature, ${ }^{\circ} \mathrm{C} ; \mathrm{C}=$ soil temperature at $30 \mathrm{~cm},{ }^{\circ} \mathrm{C} ; \mathrm{D}=$ total rainfall, $\mathrm{mm} ; \mathrm{E}=$ number of days with more than $0.2 \mathrm{~mm}$ rain; $\mathrm{F}=$ number of days with an air frost.

minimum temperature less than $0^{\circ} \mathrm{C}$, number of days with an air frost, mean soil temperature at $30 \mathrm{~cm}$ and $100 \mathrm{~cm}$ below the surface (both recorded at $9.00 \mathrm{am}$ ), total rainfall and number of days on which 
rainfall exceeded $0.2 \mathrm{~mm}$ and $1.0 \mathrm{~mm}$. Six of these measurements are illustrated in Figure 2. There was no statistically significant association between trap deaths and any single weather variable though in general high levels of trap deaths seem linked to low temperatures (particularly in C. glareolus, and to a lesser degree in A. flavicollis) rather than to greater rainfall (table 10). This supports Perrin's (1975) analysis of the affect of weather on trap deaths of C. glareolus.

Table 10

Correlation coefficients from comparisons of monthly variation in specified climatic parameters and percentage trap deaths.

\begin{tabular}{|c|c|c|c|c|c|c|c|c|c|c|}
\hline \multicolumn{3}{|c|}{ Temp. air } & \multicolumn{2}{|c|}{ Temp. soil } & \multicolumn{3}{|c|}{ Precipitation, $\mathrm{mm}$} & \multicolumn{2}{|c|}{ No. of days } & \multirow[b]{2}{*}{ df } \\
\hline $\begin{array}{l}\text { mean } \\
\max \end{array}$ & $\begin{array}{l}\text { mean } \\
\text { min }\end{array}$ & $\begin{array}{l}\text { mean } \\
\text { daily }\end{array}$ & $30 \mathrm{~cm}$ & $100 \mathrm{~cm}$ & $\begin{array}{l}\text { Total } \\
\text { rain } \\
\text { fall }\end{array}$ & $\begin{array}{r}\mathrm{No} \\
\mathrm{d} \\
\geqslant \\
.2\end{array}$ & $\begin{array}{l}\text { of } \\
\text { ys } \\
\geqslant 1.0\end{array}$ & $\begin{array}{c}\text { Air } \\
\text { frost }\end{array}$ & 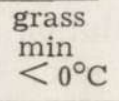 & \\
\hline-.08 & -.12 & -.09 & -.06 & \begin{tabular}{l} 
A. syl \\
\hdashline .11 \\
A. fla?
\end{tabular} & $\begin{array}{c}\text { vaticus } \\
0 \\
\text { vicollis }\end{array}$ & .07 & .04 & 0 & .04 & 27 \\
\hline-.24 & -.23 & -.21 & -.21 & $\begin{array}{l}-.21 \\
\text { C. } g l a\end{array}$ & $\begin{array}{c}.05 \\
\text { areolus }\end{array}$ & .13 & .08 & 0 & .24 & 27 \\
\hline-.32 & -.35 & -.34 & -.28 & -.23 & .11 & .02 & .08 & .27 & .24 & 27 \\
\hline
\end{tabular}

The Relative Importance of Weather, Biological Variables and the Index of Experience

The importance of each of three kinds influences on the incidence of trap deaths was assessed in a multiple linear regression analysis (Johnson \& Leone, 1964). This allowed the computation of the coefficients of determination (see for example Seber, 1977) which express the proportion of variation in the incidence of trap deaths accounted for by a given set of variables. Variables which were associated with trap deaths were selected from earlier results. Five weather variables, two biological variables and the sindex of experience" were included in this analysis (see Table 11).

The analysis was carried out in a stepwise fashion commencing with the weather variables alone, then weather plus biological variables and finally weather and biological variables plus the "index of experience ". Weather variables alone accounted for over $32 \%$ of the variation in the incidence of trap deaths of C. glareolus whereas in both Apodemus species the influence of weather was of limited importance $(12 \%$ and $15 \%$ in A. sylvaticus and A. flavicollis respectively). Biological parameters were particularly important in A. sylvaticus increasing the explain$\in d$ portion of variance by approximately $34 \%$. These parameters were also of some importance in $A$. flavicollis but in C. glareolus their impact was negligible. "Experience« also seems to have a role in the occurrence of trap deaths in A. sylvaticus and A. flavicollis though the association 
between trap deaths and experience was much greater in the latter.

The relative importance of weather, biological variables and experience was different in all three rodent species. Only weather was of any importance in trap mortality of C. glareolus; biological parameters were of major importance in the death of A. sylvaticus and in A. flavicollis

Table 11

Coefficient of determination (S e ber, 1977) expressed as the percentage of monthly variation in the incidence of trap deaths accounted for by three sets of variables; weather data includes mean minimum air temperature, soil temperature at $30 \mathrm{~cm}$, total rainfall, number of days with more than $0.2 \mathrm{~mm}$ rain and number of days grass minimum temperature less than $0^{\circ} \mathrm{C}$; biological variables are the minimum survival rate and the percentage of nnew " animals.

\section{A. sylvaticus A. flavicollis $\quad$ C. glareolus}

Weather variables only (5)

Weather variables $(5)+$ biological variables (2)

Weather variables $(5)+$ biological variables (2) + experience (1)

Variation unaccounted for

$\begin{array}{lll}12.17 & 15.09 & 32.33 \\ 45.63 & 25.49 & 34.63 \\ 54.55 & 59.88 & 38.74 \\ 45.45 & 40.12 & 61.26\end{array}$

»experience" was the principal source of variation. A substantial proportion of variance in the incidence of trap deaths remains unexplained (Table 11). This may be due to as yet unspecified parameters or inadequacies of the data used in the analyses presented in this paper.

\section{DISCUSSION}

\section{With what Factors Are Trap Deaths Associated?}

The present study and the earlier work of P e r r in (1975) and F e r n s (1978) implicate both extrinsic and intrinsic factors in the death of small rodents captured in Longworth traps. P e r r in (1975) suggests that extreme temperatures, both high and low, and heavy rainfall increase trap mortality of $M$. agrestis and C. glareolus. F e rn s (1978), however, found no temperature effects on the death rate of M. agrestis. His results also differed from those of Perrin (1975) in that rainfall had a negative relationship with the incidence of trap mortality i.e. trap deaths increased during periods of low rainfall. Ferns suggested that deaths may occur through dehydration exacerbated by high temperatures. The present paper also implicates weather in trap mortality. The results were not statistically significant but the data concurred with Perrin (1975), in that rainfall appeared to influence mortality of C. glareolus; moreover, excess rainfall rather than drought was the cause. However C. glareolus was more strongly affected by low temperatures. Trap deaths of both Apodemus species were independent of rainfall and temperature (Table 10). The importance of inclement 
weather in the incidence of trap deaths of $C$. glareolus and its unimportance with regards to trap deaths of $A$. sylvaticus and A. flavicollis, is confirmed in the multiple regression analysis presented in Table 11. Weather variables accounted for some $32 \%$ of overall variance in the percentage of trap deaths of $C$. glareolus whereas the comparable figures for $A$. sylvaticus and $A$. flavicollis were $12 \%$ and $15 \%$ respectively. Clearly the latter two species seem to be more tolerant of extreme weather conditions while subject to the stresses of capture, confinement and possibly recapture. However it must be noted that the weather data was recorded at a meteorological station some $20 \mathrm{~km}$ north of Woodchester Park and while this undoubtedly will reflect general trends in the climate of the latter, microciimatic effects in the woodland in which trapping was carried out were not assessed. For example vegetation could have moderated the effects of extreme high and low temperatures and also prolonged the effects of rainfall. Consequently, correlations revealed here between weather variables and trap deaths of C. glareolus, A. sylvaticus and A. flavicollis must be regarded as minimum estimates.

P latt (1968) described a positive association between changes in population density and trap mortality of Blarina brevicauda, C. gapperi and Peromyscus leucopus. He postulated that this relationship resulted from increased "stress" at high population densities, an idea severely criticised by Ferns (1978). Both Perrin (1975) and Ferns (1978) found little to support Plat t's (1968) assertion and the present report also suggests little relationship between trap deaths and the population density of $A$. sylvaticus, A. flavicollis and C. glareolus (Table 6). However Platt's (1968) data also fits the hypothesis that population survival, as opposed to population density, influences the incidence of trap mortality. Ferns (1978) found this to be the case in M. agrestis and this was also evident in the A. sylvaticus population at Woodchester Park (Table 6), where trap deaths were more frequent when minimum survival rates were low. In A. flavicollis and C. glareolus, on the other hand, the incidence of trap deaths was unrelated to survival. Ferns (1.978) demonstrated that trap deaths occurred more frequently among animals that had not been captured previously. This was also true for the A. sylvaticus and C. glareolus populations of the present study (Tables 4 and 7). The proportion of such naive animals in any month varied considerably throughout the study (Table 5) and this variation was correlated positively, though not significantly, with the incidence of trap deaths in A. sylvaticus and C. glareolus (Table 6). Clearly biological parameters could be important in causing trap deaths. Here minimum survival and the appearance of "new or naive animals had 
greatest impact in A. sylvaticus where these account for some $33.5 \%$ of overal variation in the incidence of trap deaths (Table 11). This perhaps reflects the suggested role of adult male aggression in determining population survival and population size of this species (W a t ts, 1969; Flowerdew, 1974; Gurnell, 1978). It is conceivable that this aggression could weaken the mice such that survival of the populations as a whole and of mice caught in traps is reduced.

There was a general decline in the incidence of trap deaths of A. sylvaticus, A. flavicollis and C. glareolus as the Woodchester Park study continued (Fig. 1). This was clear from the significant negative associations between trap deaths and the sindex of experience " in all three species. However multiple regression analyses suggest that in $A$. sylvaticus and C. glareolus this association seems to result from directional changes in other factors towards the end of the study. For example rainfall was low in the drought years of 1975 and 1976 compared to 1974 and survival of A. sylvaticus was better relatively in the latter half of the trapping programme. However in A. flavicollis the effect of the sindex of experience seems to be the major influence on trap deaths accounting for approximately $34.5 \%$ of total variation (Table 11). Now it seems unlikely that experience in trapping and maintaining captured animals should have had such a large and increasing effect on limiting trap deaths throughout the study. It seems more likely that the highest level of expertise was gained within a few months of the start of the work and then remained at this level. This could not account for the observed negative correlation between trap deaths and the sindex of experience". Therefore it is suggested that this arbitrary measurement has little to do with actual experience and, in A. flavicollis, in independent of factors such as population survival and weather. By process of elimination this leaves the intriguing but disquieting possibility that the sindex of experience " was associated with some qualitative change in the A. flavicollis population with regards to survival of captured animals. In other words throughout the study there could have been selection against those animals which died in traps such that those phenotypes which survive confinement in traps, became increasingly more prevalent in later generations. This process may have been particularly important in the A. flavicollis population since, at Woodchester Park, this species was often present in very low numbers during late winter and early spring at the onset of breeding (M o n t g o mery, 1980a). Further A. flavicollis was confined to certain small areas of woodland ( $\mathrm{Y}$ a ld e $\mathrm{n}, 1971$ ) and it was in these that the trapping effort was concentrated (M o n tgomery, $1977,1980 \mathrm{~b})$. Hence selection acting on low numbers may have produced 
a sbottleneck" effect leading to greater tolerance to capture within four or five generations. This process may have failed to occur in A. sylvaticus and C. glareolus since these were not so restricted within the woodland of the study site and individuals which died in traps could be replaced by those moving in from peripheral areas. The possibility of selection through interference with a rodent population is seldom considered. Results here suggest that in dealing with a population whose overall density is low and which is restricted to a few small patches of habitat, changes in genetic composition ought not to be ignored.

\section{Which Animals Die in Traps?}

C. glareolus was more vulnerable to trap death than either A. sylvaticus or A. flavicollis. This may be accounted for by the absence of an evening trap round throughout the trapping programme and it is uncertain whether the observed result reflects some basic difference in the tolerance of $C$. glareolus and Apodemus to confinement in traps. Individual $C$. glareolus, being diurnal, may have had increased periods of confinement relative to Apodemus and hence increased likelihood of dehydration, starvation, heat loss, physiological or psychological stress or any other immediate cause of death. The only intraspecific variation in the incidence of trap death also occurred with C. glareolus. ln this species juveniles were more liable to die while captive (Table 1). This was probably related to the marked tendency of lighter animals to die in traps which was apparent in all three species (Table B). Increased incidence of trap death among individuals in the lighter weight classes cannot be explained by weight loss immediately before death since although dead weight was often less than the last recorded live weight, this difference was neither consistent nor significant (Table 9). Perrin (1975) has also noted the greater susceptibility of lighter $C$. glareolus to trap death. The present study also concurs with F e r n s (1978) in that trap naive animals, at least in A. sylvaticus and C. glareolus, died in traps more frequently than those which have already experienced capture (Tables 4 and 7 ). The basis of this result is as yet undetermined though it is possible to approach this problem in two ways. The simplest explanation may be that animals which are going to die in traps do so on their first encounter with traps. On the other hand trap deaths seem to be greater among those animals which are going to be caught only once during the trapping programme. This suggests that these are in some way different from individuals which are caught several times. For example to the former group may be regarded as "transients" and the latter "residents". If this is a valid 
distinction, results here and the work of others (A ndrzejewski \& Wrocławek, 1961; Perrin, 1975; Ferns, 1978) suggest that trap deaths are more frequent among "transients" than among "residents".

Acknowledgements: It is a pleasure to thank Mr. A. R. Kelly and Fountain Forestry who granted access at Woodchester Park, Dr. D. W. Yalden who supervised the study and made many useful comments on earlier drafts of the manuseript and Mrs. E. Purdy who typed the manuscript.

\section{REFERENCES}

1. Andrzejewski R. \& Wroclawek H., 1961: Mortality of small rodents in traps as an indication of the diminished resistance of the migrating part of a population. Bull. Acad. Pol. Sci. Cl. II Ser. Sci., 11: 491-492.

2. Chitty D., 1959: A note on shock disease. Ecology, 40: 728-731.

3. Chitty D. \& Kempson D. A., 1949: Prebaiting small mammals and a new design of live trap. Ecology, 30: 536-542.

4. Chitty D. \& Phipps E., 1966: Seasonal changes in survival in mixed populations of two species of vole. J. Anim. Ecol., 35: 313-331.

5. Corke D., 1919: The deaths of small mammals in live-traps. J. Zool., Lond., 153: 552 .

6. Ferns P. N., 1978: Trap mortality in Microtus agrestis (L). Z. f. Säugetierkunde, 43: $92-101$.

7. Fullaga r J. J., 1967: Molt in field mice and the variation in chest markings of Apodemus sylvaticus (Linne, 1758) and Apodemus flavicollis (Melchior, 1834). Säugetierk. Mitt., 15: 138-148.

8. Fullagar J. J. \& Jewell P. A., 1965: Marking small rodents and the difficulties of using leg rings. J. Zool., Lond., 147: 224-228.

9. Flowerdew J. R., 1974: Field and laboratory experiments on the social behaviour and population dynamics of the Woodmouse (Apodemus sylvaticus). J. Anim. Ecol., 43: 499-511.

10. Gurnell J., 1978: Seasonal changes in numbers and male behavioural interaction in a population of Wood mice, Apodemus sylvaticus. J. Anim. Ecol, 47: $741-755$.

11. I verson S. L. \& Turner B. N., 1969: Under-snow shelter for small mammal trapping. J. Wildl. Mgmt., 33: 722-723.

12. Johnson N. L. \& Le one F. C., 1964: Statistics and experimental design in engineering and the physical sciences. Vol. 1. John Wiley and Sons, New York. 1964.

13. Miller D. H. \& G e t z L. L., 1968: A method to reduce winter trap mortality. J. Mammal., 49: 147.

14. M ontgomery W. I., 1977: Studies on the ecology of two sympatric species of Apodemus (Rodentia: Muridae). Unpubl. PhD thesis University of Manchester.

15. M o n tg o mery W. I., 1980a: Population structure and dynamics of sympatric Apodemus species (Rodentia: Muridae). J. Zool., Lond.

16. Montgomery W. I., 1980b: Spatial organisation in sympatric populations in Apodemus sylvaticus (L.) and A. flavicollis (Melchior) (Rodentia: Muridae). J. Zool., Lond.

17. Perrin M. R., 1975: Trap deaths. Acta theriol., 20: 167-174. 
18. Platt A. P., 1968: Differential trap mortality as a measure of stress during times of population increase and decrease. J. Mammal., 49: 331-335.

19. S a d leir R. M. F. S., 1965: The relationship between agonistic behaviour and population changes in the deermouse, Peromyscus maniculatus (Wagner). J. Anim. Ecol., 34: 331-352.

20. Seber G. A. F., 1977: Linear regression analysis. J. Wiley and Sons, New York.

21. S haw M. W. \& Milner C., 1967: The use of insulating covers for Longworth traps. J. Zool., Lond., 153: 546-551.

22. Watts C. H. S., 1969: The regulation of Wood mouse (Apodemus sylvaticus) numbers in Wytham Woods, Berkshire. J. Anim. Ecol., 38: 285-304.

23. Yalden D. W., 1971: A population of Yellow-necked mouse, Apodemus flavicollis. J. Zool., Lond., 164: 244-250.

Accepted, April 10, 1980.

\section{W. I. MONTGOMERY}

\section{SMIERTELNOSC DROBNYCH SSAKOW W ŻYWOEOWKACH}

\section{Streszczenie}

Omówiono rozmiary i przyczyny śmiertelności pułapkowej sympatrycznych popopulacji Apodemus sylvaticus, A. flavicollis i Clethrionomys glareolus w zachodniej Anglii, w czasie 30-miesięcznych odłowów. Najwyższą śmiertelność wykazywały nornice, zwłaszcza osobniki młode (Tabela 1, 2). Wyższą śmiertelność miały również te osobniki A. sylvaticus i C. glareolus, które uprzednio nigdy nie złowiły się w żywołówki lub łowiły się rzadko. Potwierdza to analiza złowień tych gryzoni, przeprowadzona dla okresów 4-dniowych (Tabela 3, 4, 6). Wyniki sugerują, że zwierzęta które mogą stanowić migrującą część populacji, są bardziej podatne na padanie w pułapkach (Tabela 7). Podobnie reagują lżejsze osobniki łowionych gatunków (Tabela 8,9 ). Na podstawie międzygatunkowych porównań autor sugeruje, że sezonowe zmiany w procencie śmiertelności w pułapkach były podobne u myszy zaroślowej, leśnej i u nornicy (Tabela 5, Ryc. 1). Jednakże czynniki towarzyszące tym zmiantom są różne $u$ tych trzech gatunków gryzoni (Tabela 10,11). Smiertelność pułapkowa nornic dość wyraźnie związana jest z warunkami pogody, szczególnie z niską temperaturą (Ryc. 2). Ogólnie słaba przeżywalność całej populacji myszy zaroślowej jest przyczyną jej zwiększonej śmiertelności w pułapkach. Proporcje śmiertelności pulapkowej u A. flavicollis obniżają się w miarę trwania eksperymentu. Tu obniżanie się nie było związane z żadnym czynnikiem zewnętrznym czy wewnętrznym i możliwe jest, że intensywnie prowadzony odłów małej, mozaikowo rozmieszczonej populacji może prowadzić do wyselekcjonowania fenotypu dobrze przeżywającego złowienia, który staje się przeważający pod koniec doświadczenia. 